\title{
Persepsi Pengusaha Industri Sanitair Terkait Tingkat Literasi Keuangan
}

\author{
Dewi Sofiana \\ Fakultas Ekonomi Universitas Negeri Malang \\ Email: Dewisofiana76@yahoo.com
}

\begin{abstract}
The purpose of this research was to find perception Sanitair industrial central's businessman associated of financial literacy level, financial literacy pattern, and impact of financial literacy to the people in surrounding. This research is using qualitative and designed for qualitative case study. The research is conducted in sanitair businessman's community. The researcher did a research before having problems by using interviews and observations. The analysis techniques used are data reducing, data display and conclusion.The conclusion of the research showed that there are 3 levels; well literate, sufficient literate, and less literate. All of them are making a positive pattern and medium level. Financial literacy is not giving impact to the people in surrounding but it is giving impact to the businessman and through the industry it will give an impact to the people in surrounding.
\end{abstract}

Keywords: Financial Literacy Level, Financial Literacy Pattern, Sanitair Industrial Central's

\section{PENDAHULUAN}

Banyak individu yang kurang memiliki pengetahuan keuangan, baik pengetahuan dasar apalagi yang lebih kompleks. Padahal literasi keuangan menjadi hal yang tidak terpisahkan dalam kehidupan seseorang karena literasi keuangan merupakan alat yang berguna untuk membuat keputusan keuangan. Pengetahuan keuangan yang rendah akan menyebabkan pembuatan rencana keuangan yang salah karena kesulitan keuangan tidak hanya disebabkan oleh rendahnya pendapatan, akan tetapi kesulitan keuangan juga dapat muncul jika terjadi kesalahan dalam pengelolaan keuangan.

Mempraktikan pengetahuan ilmu keuangan dalam kehidupan sehari-hari memang sangat penting untuk dimiliki setiap masyarakat. Terlebih masyarakat yang menjalankan usaha untuk memenuhi kebutuhan mereka, para pengusaha seharusnya menerapkan ilmu keuangan untuk mengelola usaha yang dijalankannya. Hal ini digunakan untuk pengelolaan pendapatan dengan benar sehingga usaha yang dijalankannya bisa berkembang dan meluas. Tidak hanya untuk pembagian pendapatan saja, dalam hal keberlanjutan usaha pengelolaan keuangan juga sangat penting. Selain untuk kepentingan pribadi, penerapan ilmu keuangan dengan benar yang akan mempengaruhi usahanya juga akan berampak kedaerah sekitar. Dimana semakin berkembang usaha yang dijalankannya maka semakin meningkat perekonomian daerah tersebut.

Diperkuat dengan hasil studi pendahuluan yang telah dilakukan di daerah sentra industri sanitair Kelurahan Karang Besuki Malang. Dari data yang diperoleh, 
masing-masing pengusaha belum memanfaatkan layanan jasa dan produk lembaga keuangan yang ada. Padahal layanan lembaga keuangan akan sangat membantu transaksi-transaksi usaha dan bisa mempermudah perluasan penjualan. Dengan studi pendahuluan tersebut, peneliti juga menemukan fenomena-fenomena sebagai berikut.

Pertama, pembukaan usaha didasari oleh faktor usaha turun temurun. Pengusaha hanya mempelajari proses produksi, sedangkan pengelolaan keuangan yang berguna untuk keberlanjutan usahanya tidak diwariskan. Kedua, industri sanitair sangat dipengaruhi oleh pemasok bahan baku, yaitu semen dan besi sehingga output dan fluktuasi pada bahan baku akan mempengaruhi biaya produksi yang pada akhirnya mengurangi keuntungan, apalagi pengusaha sanitair tidak mencatat pemasukan serta pengeluaran dalam kegiatan industrinya. Ketiga, pemenuhan kewajiban terhadap warga sekitar industri kurang maksimum, karena belum adanya kejelasan pengelolaan organisasi yang mengelola paguyuban daerah tersebut.

\section{KAJIAN PUSTAKA}

Hendiks (2010) dalam Febriandi (2014), literasi keuangan dapat digambarkan sebagai kemampuan untuk membuat penilaian informasi dan mengambil tindakan efektif mengenai penggunaan saat ini dan masa depan dalam pengelolaan uang. Literasi keuangan mencakup kemampuan untuk memahami pilihan keuangan, merencanakan masa depan, mengeluarkan uang secara bijaksana, dan mengelola tantangan yang berkaitan dengan peristiwa kehidupan seperti tabungan pensiun, ketika kehilangan pekerjaan atau untuk membayar biaya pendidikan.

Kemudian Jumpstart Coalition dalam Huston, (2010) menyatakan bahwa "Financial Literacy is the ability to use knowledge and skills to manage financial resources effectively for lifetime financial security". Hal ini berarti bahwa literasi keuangan merupakan kemampuan dan keahlian untuk mengelola keuangan dalam rangka persiapan kesejahteraan kehidupan dalam jangka panjang. Australian Securities \& Investments Commission (report, 229, March 2011) dalam Satrio (2012) menyatakan bahwa: Dalam mendalami dan mengetahui seberapa besar tingkat Financial literacy seseorang dapat menggunakan tolak ukur pengetahuan sebagai berikut:

a. Pengetahuan seseorang atas nilai suatu barang dan skala prioritas dalam hidupnya;

b. Penganggaran, tabungan dan bagaimana mengelola uang;

c. Pengelola kredit;

d. Pentingnya asuransi dan melindungi terhadap resiko;

e. Dasar-dasar investasi;

f. Pensiunan;

g. Perencanaan pensiun;

h. Pemanfaatan dari belanja dan membandingkan produk;

i. Dimana harus pergi mencari saran dan informasi bimbingan dan dukungan tambahan;

j. Bagaimana mengenali potensi konflik atas kegunaan (prioritas). 
Pengkategorian tingkatan literasi keuangan berdasarkan hasil survei nasional literasi keuangan yang dilakukan oleh Otoritas Jasa Keuangan, tingkat literasi keuangan masyarakat Indonesia diklasifikasikan dalam 4 tingkatan yaitu:

\section{Well Literate}

Memiliki pengetahuan dan keyakinan tentang lembaga jasa keuangan serta produk dan jasa keuangan termasuk fitur, manfaat dan resiko, hak dan kewajiban terkait produk dan jasa keuangan, serta memiliki ketrampilan dalam menggunakan produk dan jasa keuangan.

\section{Sufficient Literate}

Memiliki pengetahuan dan keyakinan tentang lembaga jasa keuangan serta produk dan jasa keuangan termasuk fitur, manfaat dan resiko, hak dan kewajiban terkait produk dan jasa keuangan.

\section{Less Literate}

Hanya memiliki pengetahuan tentang lembaga jasa keuangan, produk dan jasa keuangan.

\section{Not Literate}

Tidak memiliki pengetahuan dan keyakinan tentang lembaga jasa keuangan serta produk dan jasa keuangan, serta tidak memiliki ketrampilan dalam menggunakan produk dan jasa keuangan.

\section{METODE}

Metode penelitian ini menggunakan pendekatan kualitatif. Menurut Sukmadita (2010) menyatakan bahwa, penelitian ini ditunjukan untuk memahami fenomenafenomena sosial dari sudut perspektif informan sebagai narasumber. Informan adalah orang-orang yang diajak berwawancara, diobservasi, diminta memberikan data, pendapat, pemikiran dan persepsinya.

Lokasi penelitian ini bertempat di senta industri Sanitair di Kelurahan Karang Besuki, Malang. Sumber data yang digunakan adalah sumber data primer dan sekunder. Untuk sumber data primer diperoleh dari hasil wawancara langsung kepada pengusaha industri sanitair di Kelurahan Karang Besuki, Malang. Sedangkan data sekunder digunakan sebagai data penguat, data diperoleh dari staff Kelurahan Karang Besuki dan juga Anggota pengelola sumbangan dari pengusaha industri sanitair.

Prosedur pengumpulan data menggunakan beberapa metode. Langkah pertama yaitu melakukan observasi yang dimaksudkan untuk mengungkap fenomena dan situasi dengan melihat kondisi dan situasi di lapangan. Langkah selanjutnya melakukan wawancara langsung kepada responden yang telah ditentukan untuk memperoleh data yang lebih mendalam. Dalam proses wawancara disertai dengan melakukan proses dokumentasi yakni berupa foto, catatan lapangan dan juga rekaman.

Dari data yang telah diperoleh tersebut dianalisis dengan maksud memusatkan dan menggolongkan data sesuai dengan fokus permasalahan. Dari data yang sudah direduksi,sekumpulan data tersebut dikumpulkan dan disusun daam bentuk teks naratif selanjutnya adalah menarik kesimpulan. Untuk mengecek keabsahan temuan dilakukan menggunakan teknik triangulasi sumber dan waktu. 
Tahap-tahap penelitian memiliki beberapa tahap. Pertama, tahap pralapangan melakukan studi pendahuluan atau observasi awal merupakan suatu kegiatan awal yang dilakukan oleh peneliti sebelum menyusun proposal penelitian. Kedua penyusunan proposan penelitian dilakukan dengan didasari oleh apa yang telah dihasilkan atau temuan dari studi pendahuluan, kajian literatur mengenai tingkat literasi keuangan, dan juga kajian literatur mengenai literasi keuangan. Ketiga pengumpulan data yang mana terjun langsung ke lapangan guna melakukan wawancara kepada responden. Kemudian menganalisis data dan menyajikan data dalam bentuk karya ilmiah.

\section{HASIL DAN PEMBAHASAN}

Berdasarkan pengertian yang mendasari Austrian Seciruies \& Investments Commission report, 229, March 2011) yang merupakan pengertian internasional tentang literasi keuangan adalah pengetahuan, pemahaman dan kemampuan yang tidak hanya dalam mengatur keuangan tapi juga merupakan pengetahuan yang dapat membantu kita dalam membuat pertimbangan dan keputusan ekonomi. Sedangkan menurut Otoritas Jasa Keuangan (OJK) literasi keuangan adalah suatu rangkaian atau aktivitas untuk meningkatkan pengetahuan (Knowledge), keyakinan (confidence), dan keterampilan (skill) konsumen dan masyarakat luas sehingga mereka mampu mengelola keuangan dengan lebih baik.

\section{Perspektif Pengusaha Indutri Sanitair Terkait Tingkat Literasi Keuangan}

Melihat dan merujuk dari pengertian di atas serta menurut hasil penelitian yang dilakukan peneliti, berdasarkan konsep tersebut dapat diketahui ada 3 tipe tingkatan literasi keuangan yang ada di pengusaha sentra industri sanitair di Kelurahan Karang Besuki Malang. Tiga tingkatan tersebut adalah well literate, sufficient literate, dan less literate. Masing-masing pengusaha memiliki kemampuan yang berbeda dalam mengelola keuangan, pemikiran masa depan dan penyelesaian atas konflik keuangan.

Pengusaha dengan tingkatan literasi keuangan Well Literate, mampu mengkombinasikan cara pengelolaan dan penggunaan dananya untuk kebutuhan dan permodalan usahanya dan mampu meningkatkan pendapatannya melalui pengembangan usaha lainnya. Dalam hal menggunakan uangnya, untuk usaha maupun untuk masalah pribadi. Responden pada tingkatan ini cenderung menggali informasi terlebih dahulu secara lengkap sebelum memulai usahanya, seperti bagaimana mengawalinya, pengelolaan usaha dan sebagainya. Hal ini memperlihatkan bagaimana responden cenderung membuat kebijakan atau keputusan-keputusan atas segala tindakannya sangat analitis, efektif dan efisien berdasarkan pertimbangan-pertimbangan tersebut. Pengelolaan keuangan yang dilakukan oleh responden, mereka lebih memiliki pengetahuan yang cukup lengkap. Walaupun tidak sepenuhnya responden membuat pencatatan secara tertulis dan 
terperinci, namum sistem penganggaran uang dilakukan sudah terstruktur tapi dari biaya kebutuhan konsumsi dan produksi hingga menentukan tindakan yang tepat.

Pengusaha pada tingkatan Sufficient Literate, pengelolaan keuangan mereka condong kepada pemikiran bagaimana pendapatan yang mereka terima bisa memenuhi kebutuhan tanpa meningkatkan nilai tambah pendapatan mereka sendiri. Pada tipe ini sebagian besar tidak membuat pencatatan secara tertulis, penganggaran yang mereka ciptakan setelah terbayang atas kebutuhan yang mereka inginkan. Pengusaha pada tingkatan Less Literate, mengkombinasikan pengelolaan dan penggunaan dananya untuk kebutuhan pribadi, untuk memenuhi kebutuhan responden tidak pernah membuat perencanaan yang jelas hanya sekedar penganggaran untuk kebutuhan pokok dan wajib saja. Dalam hal menyimpan dana responden cenderung tidak penah melakukanya, sehingga tidak terdapat penganggaran khusus untuk penyimpanan dana. Pengusaha dengan tipe ini cenderung menganggap permasalahan keuangan adalah hal yang wajar dan dapat dengan mudah terselesaikan, dibuktikan dengan responden sering menyelesaikan permasalahan yang muncul dengan dana pinjaman.

\section{Pola Literasi Keuangan Pengusaha Sentra Industri Sanitair}

Tingkat literasi keuangan pengusaha sentra industri sanitair yang berada pada Kelurahan Karang Besuki Malang mempunyai pola hubungan positif antar indikator. Dimana Input setiap pengusaha yakni pendidikan, usia dan juga lama membuka usaha akan mempengaruhi output mereka yakni pengetahuan ilmu keuangan dan pengelolaan keuangan serta pendapatan mereka.

\section{Dampak Literasi Keuangan Terhadap Kesejahteraan Masyarakat Di Daerah Industri Sanitar}

Penggolongan tingkat literasi keuangan pada pengusaha sentra industri sanitair tidak ada perbedaan pemberian bantuan kepada masyarakat oleh golongangolongan tersebut. Para pengusaha akan membantu dengan suka rela kepada penduduk di kelurahan Karang Besuki untuk pembangunan daerah tersebut. Hal itu disebabkan oleh tingkatan literasi keuangan yang mereka miliki hanya berdampak kepada diri sendiri dan usahanya.

Bantuan dapat dibedakan menjadi 2 yakni secara materi dan non materi. Bantuan secara materi yakni seperti bantun uang dan bantuan barang ornamen, bantuan ini diberikan kepada masyarakat miskin, kaum duafa dan juga anak yatim. Sedangkan untuk bantuan yang berupa barang ornamen diperuntukkan kepada masyarakat miskin yang hendak memperbaiki bangunan rumahnya, untuk bangunan tepat ibadah dan juga untuk memperbaiki kepentingan bersama didaerah tersebut misalnya gorong-gorong dan pot-pot penghijauan. Bantuan yang kedua yakni bantuan non materi seperti pengalaman dan ketrampilan ketika warga mau bekerja serta belajar disalah satu industri yang berada disana. 


\section{Ketertaitan Antara Tingkat, Pola Dan Dampak Literasi Keuangan}

Dalam penelitian ini mengetahui sebuah pola literasi keuangan pengusaha sentra industri sanitair perlu untuk mengetahui tingkat literasinya terlebih dahulu. Hal ini diperuntukan agar peneliti mengetahui pola yang terbentuk di komunitas responden memiliki pola baik, sedang atau buruk. Dalam pembentukan pola, tingkatan literasi keuangan memiliki pola yang sama. Meskipun pada akhirnya setelah pola literasi keuangan diketahui, tingkat literasi keuangan tidak memiliki pengaruh yang besar. Hanya berpengaruh terhadap output yang dihasilkan, misalnya responden memiliki literasi keuangan yang tinggi maka responden juga memiliki input yang bagus sehingga menghasilkan output yang bagus. Begitu pula dengan tingkat literasi keuangan yang sedang dan rendah dalam mempengaruhi pola.

Kemudian tingkat literasi keuangan juga memiliki hubungan yang positif terhadap dampak literasi keuangan. Hal ini dibuktikan dengan semakin tinggi tingkat literasi responden maka semakin besar pula kesejahteraan pengusaha karena sudah bisa memanage keuangan dengan benar. Selain itu tingkat literasi yang tinggi juga akan berdampak kepada pemasukan, karena responden akan lebih bijak dalam menjalankan usahanya. Akan tetapi tingkat literasi keuangan disini tidak memiliki hubungan kepada dampak kepada kesejahteraan masyarakat. Karena dalam penelitian ditemukan bahwa pengusaha bersama-sama mensejahterakan masyarakat tanpa mempedulikan seberapa besar mereka mengetahui ilmu keuangan dan mengaplikasikan kepada usahanya.

\section{KESIMPULAN}

Pola literasi keuangan yang terbentuk di pengusaha sanitair Karang Besuki Malang yakni pola literasi keuangan positif dengan tingkatan sedang. Hal ini ditunjukan dengan pengusaha yang telah mampu memilih barang yang berkualitas agar tidak memiliki rugi waktu dan rugi biaya; sudah mempunyai investasi untuk kehidupan jangka panjang; memilih memenuhi kewajiban dan pemenuhan usaha sebelum kebutuhan pribadi dan memiliki kesadaran untuk memberi bantuan kepada masyarakat luas.

Tingkat Literasi keuangan pengusaha memiliki dampak kepada kesejahteraan dirinya sendiri dan juga kepada kemajuan usahanya, tetapi tidak memiliki pengaruh terhadap kesejahteraan masyarakat sekitar. Sedangkan usaha yang dijalankan memiliki dampak yang positif kepada perekonomian daerah Karang Besuki dan kesejahteraan masyarakat.

Adapun saran yang dapat diajukan dari hasil penelitian ini, diharapkan pihak pemerintah agar dapat membentuk sebuah lembaga yang memperdayakan dan memberi pengetahuan tentang pengelolaan keuangan yang benar sehingga masyarakat mampu mengembangkan dan mengajarkan tentang pengetahuan dalam mengelola dan menggunakan sumber keuangannya. kepada pengusaha agar meningkatkan pemahaman mereka tentang literasi keuangan, hal ini dapat 
dilakukan dengan langkah awal membuat perencanaan penggunaan dana secara terstruktur dengan memperhatikan tingkat kebutuhan prioritasnya, sehingga mencapai apa yang mereka inginkan dalam mensejahterakan kehidupannya.

Kepada Pengembang Ilmu hendaknya memperbanyak subjek penelitian dan diharapkan dapat memperdalam observasi penelitian untuk memperkaya data dan dapat digunakan untuk perbandingan temuan, serta peneliti selanjutnya diharapkan lebih fokus saat pengumpulan data karena hal itu dapat berpengaruh pada hasil dari penelitian yang dilakukan.

\section{Daftar Rujukan}

Febriandi, Very. 2014. Analisis Tingkat Literasi Keuangan Mahasiswa Fakultas Ekonomi Universitas Negeri Malang (Studi Kasus pada Mahasiswa Jurusan Ekonomi Pembangunan Angkatan 2012 Pengguna Layanan Branchless banking). Skripsi Tidak di Terbitkan. Malang: FE UM.

Satrio, Y. D. 2012. Analisis Tingkat Financial Literacy Mahasiswa Fakultas Ekonomi Universitas Negeri Malang. Tesis tidak diterbitkan. Malang: FE.

OJK. 2013. Strategi Nasional Literasi Keuangan Indonesia. Jakarta: Direktorat Informasi dan Edukasi.

Huston, S.J. 2010. Measuring financial literacy. Journal of Consumers Affairs (online), 44 (2): 296-316, (http://onlinelibrary.wiley.com), diakses 12 September 2015.

Sukmadita, Nana Syaodih. 2010. Metode penelitian Pendidikan. Bandung: Remaja Rosdakatya. 